\title{
Absence of Plateau Potentials in dLGN Cells Leads to a Breakdown in Retinogeniculate Refinement
}

\author{
Emily K. Dilger, ${ }^{1}$ Thomas E. Krahe, ${ }^{1}$ Duncan R. Morhardt, ${ }^{1}$ 'Tania A. Seabrook, ${ }^{1,3}$ Hee-Sup Shin, ${ }^{2}$ and William Guido ${ }^{1,3}$ \\ ${ }^{1}$ Department of Anatomy and Neurobiology, Virginia Commonwealth University Medical Center, Richmond, Virginia 23298, ${ }^{2}$ Brain Science Institute, Korea \\ Institute of Science and Technology, Seoul 136-791, Republic of Korea, and ${ }^{3}$ Department of Anatomical Sciences and Neurobiology, University of Louisville, \\ School of Medicine, Health Sciences Center, Louisville, Kentucky 40292
}

The link between neural activity and the refinement of projections from retina to the dorsal lateral geniculate nucleus (dLGN) of thalamus is based largely on studies that disrupt presynaptic retinogeniculate activity. Postsynaptic mechanisms responsible for implementing the activity-dependent remodeling in dLGN remain unknown. We tested whether L-type $\mathrm{Ca}^{2+}$ channel activity in the form of synaptically evoked plateau potentials in dLGN cells is needed for remodeling by using a mutant mouse that lacks the ancillary $\beta_{3}$ subunit and, as a consequence, has highly reduced L-type channel expression and attenuated L-type $\mathrm{Ca}^{2+}$ currents. In the dLGNs of $\beta_{3}$-null mice, glutamatergic postsynaptic activity evoked by optic tract stimulation was normal, but plateau potentials were rarely observed. The few plateaus that were evoked required high rates of retinal stimulation, but were still greatly attenuated compared with those recorded in age-matched wild-type mice. While $\beta_{3}$-null mice exhibit normal stage II and III retinal waves, their retinogeniculate projections fail to segregate properly and dLGN cells show a high degree of retinal convergence even at late postnatal ages. These structural and functional defects were also accompanied by a reduction in CREB phosphorylation, a signaling event that has been shown to be essential for retinogeniculate axon segregation. Thus, postsynaptic L-type $\mathrm{Ca}^{2+}$ activity plays an important role in mediating the refinement of the retinogeniculate pathway.

Key words: activity-dependent refinement; $\beta_{3}$-null mice; L-type $\mathrm{Ca}^{2+}$ channel; lateral geniculate nucleus; retina; retinogeniculate

\section{Introduction}

Much of our knowledge about the activity-dependent refinement of sensory connections comes from studies that involve retinal projections to the dorsal lateral geniculate nucleus (dLGN) of thalamus (for review, see Goodman and Shatz, 1993). Recently, the retinogeniculate pathway of the mouse has emerged as a powerful model system, where the projections from the two eyes terminating in dLGN are initially diffuse and overlapping, but become organized into non-overlapping domains just before eye opening (for review, see Guido, 2008). Eye-specific segregation is also accompanied by a pruning of retinal inputs onto single dLGN cells from as many as a dozen to just one to three inputs (Chen and Regehr, 2000; Jaubert-Miazza et al., 2005). Such remodeling has been attributed to spontaneous bursts of action potentials among retinal ganglion cells (RGCs) that spread as waves across the retina (for review, see Torborg and Feller, 2005). When waves are pharmacologically or genetically disrupted, reti-

Received June 9, 2014; revised Dec. 13, 2014; accepted Jan. 11, 2015.

Author contributions: E.K.D., T.E.K., and W.G. designed research; E.K.D., T.E.K., D.R.M., T.A.S., and W.G. performed research; H.-S.S. contributed unpublished reagents/analytic tools; E.K.D., T.E.K., D.R.M., T.A.S., and W.G. analyzed data; E.K.D., T.E.K., and W.G. wrote the paper.

This work was supported by NIH Grant EY12716 (W.G.)

The authors declare no competing financial interests.

Correspondence should be addressed to William Guido, Department of Anatomical Sciences and Neurobiology, School of Medicine, Health Sciences Center, University of Louisville, Louisville, KY 40292. E-mail: william.guido@louisville.edu.

DOI:10.1523/JNEUROSCI.2343-14.2015

Copyright $\odot 2015$ the authors $\quad 0270-6474 / 15 / 353652-11 \$ 15.00 / 0$ nogeniculate projections fail to develop properly (for review, see Huberman et al., 2008).

While retinal waves are capable of driving activity in dLGN cells (Mooney et al., 1996), the postsynaptic mechanism linking retinal activity to refinement still remains unknown. NMDA receptors (NMDARs) figure prominently in many models of activity-dependent plasticity, acting like coincidence detectors to provide neurons with a $\mathrm{Ca}^{2+}$ source that can trigger plasticityrelated signaling cascades (for review, see Cohen and Greenberg, 2008). However in dLGN, large synaptically evoked depolarizations arising from retinal waves persist in the absence of NMDARs (Mooney et al., 1996). Moreover, pharmacological blockade of NMDARs does not affect eye-specific segregation (Smetters et al., 1994). A more likely candidate involves highthreshold L-type $\mathrm{Ca}^{2+}$ channels. Strong or repetitive stimulation of retinal axons evokes excitatory postsynaptic activity of sufficient amplitude and duration to activate voltage-gated L-type channels, which give rise to plateau potentials (Lo et al., 2002; Jaubert-Miazza et al., 2005; Dilger et al., 2011). These longlasting, high-amplitude depolarizations are prevalent at young ages during the period of retinogeniculate refinement. The activity-dependent $\mathrm{Ca}^{2+}$ influx associated with plateaus supports long-term changes in retinogeniculate synaptic strength (Ziburkus et al., 2009) and could initiate plasticity-related gene transcription, possibly through cAMP response element-binding protein (CREB; Mermelstein et al., 2000; Dolmetsch et al., 2001; Kornhauser et al., 2002). This signaling pathway is important 


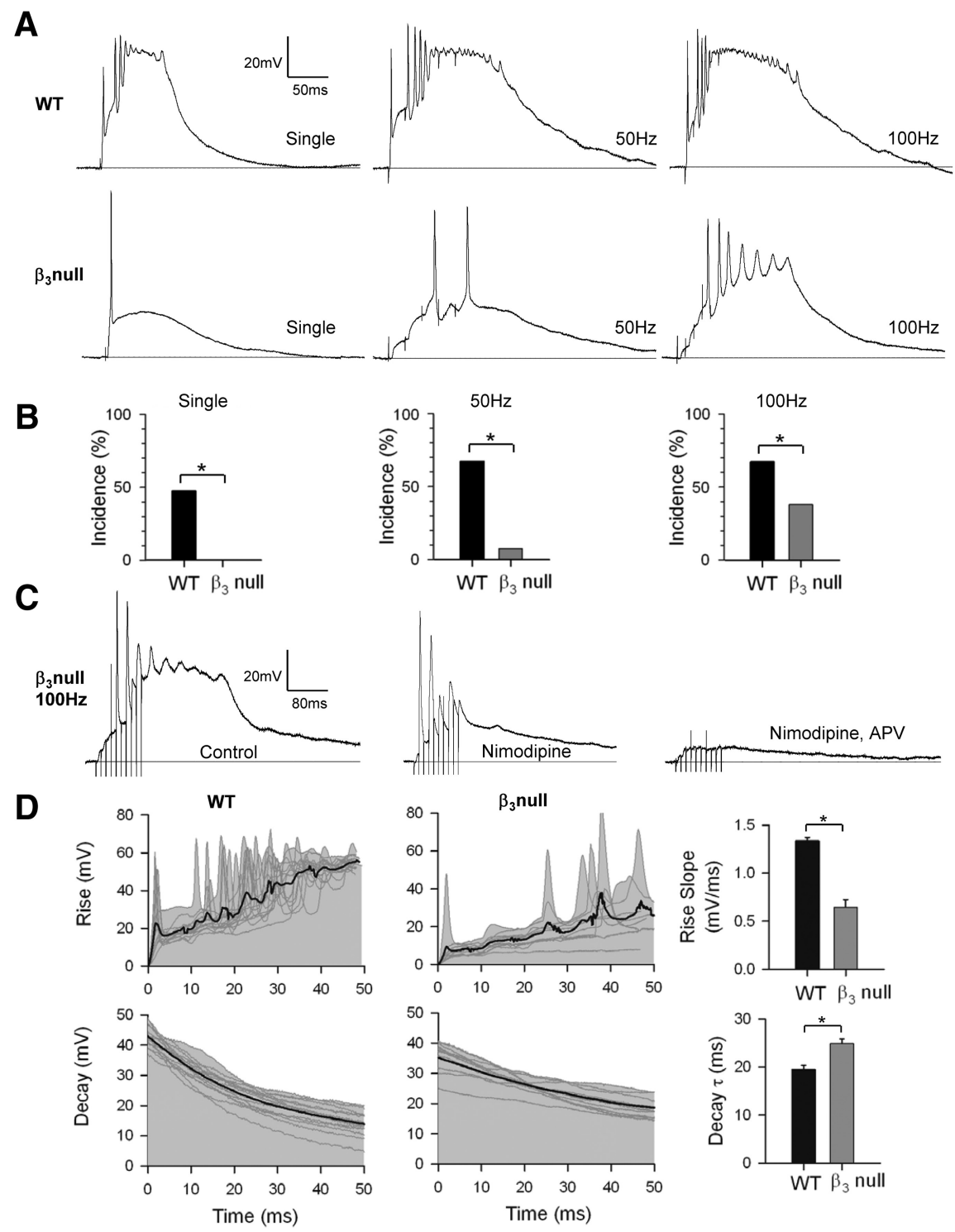

Figure 1. Plateau potentials in WT and $\beta_{3}$-null dLGN cells. $A$, Examples of synaptic responses in dLGN cells evoked by electrical stimulation of $0 T$ at early postnatal ages ( $<$ P14). In WT cells (top), single or repetitive stimulation ( $50 \mathrm{or} 100 \mathrm{~Hz}$ train of five pulses) triggered plateau activity, which is characterized as a fast-rising, high-amplitude sustained depolarization that has a burst of inactivating $\mathrm{Na}^{+}$spikes riding its crest. In $\beta_{3}$-null cells (bottom), single 0 T stimulation evokes an EPSP, but plateau activity is absent. Plateaus are rarely observed and only apparent when high rates of $0 \mathrm{~T}$ stimulation are used. $\boldsymbol{B}$, Accompanying histograms showing the incidence of plateau potentials recorded from WT cells $(n=38)$ and $\beta_{3}$-null cells $(n=26)$. Bar graphs are based on results from the study by Dilger et al., 2011. C, Example of a plateau potential in $\beta_{3}$-null cells evoked by $100 \mathrm{~Hz}$ OT stimulation recorded in normal ACSF (left), and after the bath application of nimodipine (30 $\mu \mathrm{m}$, middle) and APV (100 $\mu \mathrm{m}$, right). Initially, nimodipine blocks the plateau-like depolarization, leaving the underlying EPSP activity intact. Subsequent application of APV leads to a further reduction, indicating that high-frequency OT stimulation evokes substantial NMDA activity, an event that plays a major role in evoking plateaus (Dilger et al., 2011). D, Left and middle, Expanded traces illustrating the initial rise (top) and decay (bottom) of plateau activity in WT cells $(n=15)$ and $\beta_{3}$-null cells $(n=9)$ evoked by $100 \mathrm{~Hz}$ 0T stimulation. Gray lines show raw traces; thick black lines are averaged responses. $\boldsymbol{D}$, Right, Summary graphs showing the mean and SEM for the rise slope and decay $\tau$ for plateaus recorded in WT mice (black) and $\beta_{3}$-null mice (gray). Plateau potentials in $\beta_{3}$-null mice had slower rise and decay times than those in WT mice. ${ }^{*} p<0.001$. All responses were recorded at $-60 \mathrm{mV}$.

for the remodeling of visual connections (Pham et al., 1999; Mower et al., 2002; Tropea et al., 2006), including in the retinogeniculate pathway (Pham et al., 2001; Dhande et al., 2012; Krahe et al., 2012).

To test whether L-type-mediated plateau potentials play a role in retinogeniculate refinement, we took a loss-of-function approach and used a mouse that lacks the $\beta_{3}$ subunit of the L-type $\mathrm{Ca}^{2+}$ channel (Namkung et al., 1998). The targeted deletion of this subunit leads to a reduction in L-type activity through a decrease in membrane expression of the pore-forming $\alpha_{1}$ subunit (Bichet et al., 2000; Murakami et al., 2002; Shiraiwa et al., 2007). In dLGN of $\beta_{3}$-null mice, L-type channel expression is greatly reduced and plateau activity is almost absent (Dilger et al., 2011). What remains untested and is the focus of this article is whether the loss of dLGN plateau activity in $\beta_{3}$-null mice leads to a breakdown in retinogeniculate refinement.

\section{Materials and Methods}

All procedures were performed in compliance with the Institutional Animal Care and Use Committee at Virginia Commonwealth University. Both male and female wild-type (WT) C57BL/6 mice and a mutant mouse strain bred on a C57BL/6 background that lacks the $\beta_{3}$ subunit of the L-type $\mathrm{Ca}^{2+}$ channel were used. While the deletion of this ancillary subunit affects the expression of L-type $\mathrm{Ca}^{2+}$ channels and plateau activity in dLGN, the overall structure and function of the retina and dLGN remain similar to WT mice (Ball et al., 2002; Dilger et al., 2011). The mice were bred and housed in resident colonies and ranged in age from postnatal day 6 (P6) to P34.

Tissue preparation and in vitro electrophysiology. To examine the synaptic responses evoked by optic tract (OT) stimulation, an acute thalamic slice preparation, which preserves retinal and intrinsic inhibitory connections in dLGN, was adopted (Chen and Regehr, 2000; Dilger et al., 2011; Seabrook et al., 2013). Mice were deeply anesthetized with isoflurane inhalation and decapitated. The brain was removed from the skull and immersed in an oxygenated $\left(\begin{array}{lllll}95 \% & \mathrm{O}_{2} / 5 \% & \mathrm{CO}_{2} & 4^{\circ} \mathrm{C} \text { sucrose }\end{array}\right.$ solution (in mM: $28 \mathrm{NaHCO}_{3}, 23$ sucrose, 11 $\mathrm{MgSO}_{4}, 0.11$ glucose, $2.75 \mathrm{KCl}, 1.4 \mathrm{NaH}_{2} \mathrm{PO}_{4}$, and $0.5 \mathrm{CaCl}_{2}$ ). The two hemispheres were separated by cutting along the midline at an angle of $10^{\circ}$. The medial aspect of one hemisphere was glued onto a tilted $\left(20^{\circ}\right)$ stage of a vibratome (VT1000S, Leica), and $300 \mu \mathrm{m} \mathrm{sec-}$ tions were cut in the parasagittal plane. Before recording, slices were incubated in a holding chamber containing an oxygenated artificial CSF (ACSF) solution (in mm: $126 \mathrm{NaCl}, 26$ $\mathrm{NaHCO}_{3}, 10$ glucose, $2.5 \mathrm{KCl}, 2 \mathrm{MgCl}_{2}, 2$ $\mathrm{CaCl}_{2}, 1.25 \mathrm{NaH}_{2} \mathrm{PO}_{4}$ ) for $30 \mathrm{~min}$ at $35^{\circ} \mathrm{C}$ and then were brought to room temperature. Individual slices containing the dLGN and a large segment of OT were transferred to a recording chamber maintained at $32^{\circ} \mathrm{C}$, and perfused continuously at a rate of $2.0 \mathrm{ml} / \mathrm{min}$ with oxygenated ACSF.

In vitro recordings were performed in a whole-cell configuration with the aid of a fixed-stage microscope (E600FN, Nikon) equipped with differential interference contrast optics and a water-immersion objective to view individual neurons within the slice. Patch electrodes were pulled vertically in two stages from borosilicate glass and filled with an internal recording solution [for current clamp (in $\mathrm{mm}$ ): $140 \mathrm{~K}$-gluconate, 10 HEPES, $2 \mathrm{MgATP}, 0.3 \mathrm{NaCl}, 0.1 \mathrm{NaGTP}$, pH 7.25, and $260 \mathrm{Osm} / \mathrm{L}$; for voltage clamp (in mM): 130 Cs methanesulfonate, 10 HEPES, 10 QX-314, 


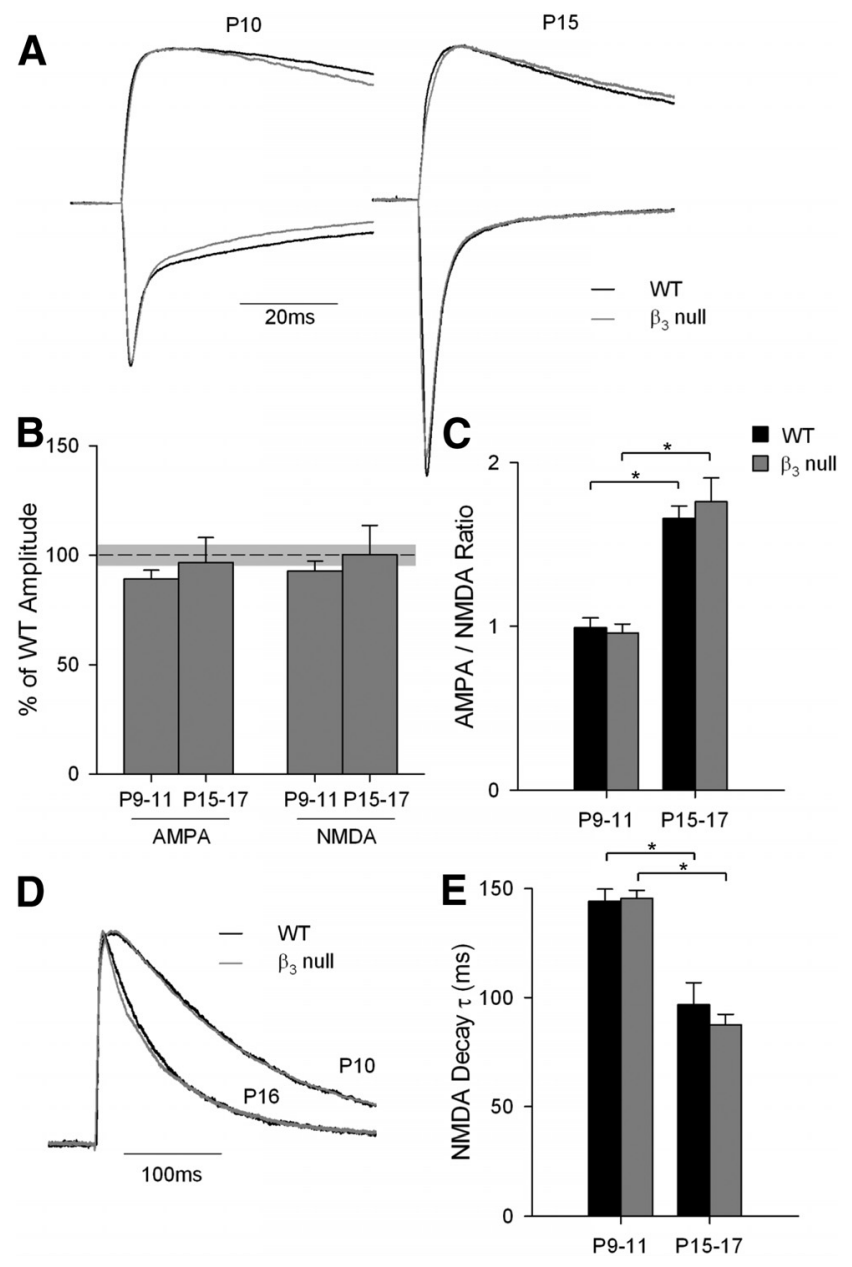

Figure 2. AMPA and NMDA currents in WT and $\beta_{3}$-null dLGN cells. $A$, Representative maximal current traces at $-70 \mathrm{mV}$ (showing the fast inward AMPAR current) and $+40 \mathrm{mV}$ (showing the slowly decaying outward NMDAR current) at P10 and P15 in WT cells (black) and $\beta_{3}$-null cells (gray). Traces are normalized to the peak NMDAR current. $\boldsymbol{B}$, Plot showing the mean and SEM maximal amplitude of AMPAR and NMDAR currents at P9-P11 and P15-P17 in $\beta_{3}$-null cells. Values are expressed relative to WT currents [mean (black dashed line) and SEM (light gray shading)]. Within each age group, the maximal currents for AMPARs and NMDARs were not different from those of WT cells. $C$, Plot of mean and SEM AMPAR/NMDAR current ratio at P9-P11 and P15-P17 for WT and $\beta_{3}$-null mice. For both groups, AMPAR currents strengthened with age. $\boldsymbol{D}$, Representative NMDAR current traces at P10 and P16 for WT and $\beta_{3}$-null mice. Traces were normalized to the peak NMDAR current. $\boldsymbol{E}$, Plot of mean and SEM NMDAR decay $\tau$ values (determined with a single exponential fit). For both groups, decay times were slower at $P 9-P 11 .{ }^{*} p<0.001$, both age groups vs condition. Responses in $\boldsymbol{A}$ and $\boldsymbol{D}$ were recorded in the presence of bicuculline, CGP, and nimodipine. $\beta_{3}$-null cells (WT cells): P9-P11 amplitude and ratio, 26 (21); $\tau, 37$ (29); P15-P17 amplitude and ratio, 22 (19); $\tau, 35$ (29).

Table 1. Spontaneous activity in WT and $\boldsymbol{\beta}_{3}$ null retinae

\begin{tabular}{lll}
\hline & P7 & P12 \\
\hline RGCs from retinae $(n)$ & & \\
$\quad$ WT & $121(3)$ & $138(3)$ \\
$\quad \beta_{3}$-null & $108(3)$ & $131(3)$ \\
Burst duration (s) & & \\
$\quad$ WT & $2.2 \pm 0.39$ & $1.09 \pm 0.023$ \\
$\beta_{3}$-null & $2.3 \pm 0.44$ & $0.74 \pm 0.081$ \\
Interwave interval (s) & & \\
$\quad$ WT & $88.2 \pm 8.6$ & $74.3 \pm 9.0$ \\
$\beta_{3}$-null & $92.1 \pm 7.0$ & $77.0 \pm 7.9$ \\
\hline
\end{tabular}

The mean (SEM) are reported for wave properties. Burst duration and interwave interval in $\beta_{3}$ null and WT retinae were not significantly different from each other (Mann-Whitney $U$ tests; all Z-values $\langle 1.7 ; p>0.1$ for all comparisons).
$5 \mathrm{KCl}, 5 \mathrm{EGTA}, 2 \mathrm{MgCl}_{2}, 0.1 \mathrm{CaCl}_{2}, 2 \mathrm{MgATP}, 0.1 \mathrm{NaGTP}$, pH 7.25, and $260 \mathrm{osmol} / \mathrm{L}]$. The final tip resistance of filled electrodes was 3-7 M $\Omega$. Whole-cell recordings were performed using an Axoclamp 2B (currentclamp) or AM Systems 2400 (voltage-clamp) amplifier. Pipette capacitance, series resistance, and whole-cell capacitance were carefully monitored and compensated for electronically during the recording. Neuronal activity was displayed on an oscilloscope (VC 6025A, Hitachi), digitized $(10-20 \mathrm{kHz})$ through an interface unit (BNC-2090, National Instruments), and stored directly on a computer. Data acquisition and analysis were accomplished using the Strathclyde Electrophysiology Software Whole Cell Analysis Program. In some cases, cells were recorded in the presence of the GABA antagonists bicuculline $(25 \mu \mathrm{M}$; catalog \#0131, Tocris Bioscience) and CGP (10 $\mu \mathrm{M}$; catalog \#1248, Tocris Bioscience), the NMDA antagonist APV (100 $\mu \mathrm{M}$; catalog \#0106, Tocris Bioscience), and the L-type antagonist nimodipine (30 $\mu \mathrm{M}$; catalog \#0600, Tocris Bioscience).

To evoke synaptic activity in dLGN, square-wave pulses $(0.1-0.3 \mathrm{~ms}$, $1-1000 \mu \mathrm{A})$ were delivered at variable rates of $(0.2-100 \mathrm{~Hz})$ through a pair of thin-gauge tungsten wires $(0.5 \mathrm{M} \Omega)$ positioned in OT. Stimulating electrodes were connected to a stimulus isolation unit (A360, World Precision Instruments) that received input from a computer-controlled, multichannel pulse generator (PulseMaster A300, World Precision Instruments).

Synaptically evoked plateau potentials were defined as long-lasting (100-500 ms), high-amplitude (35-60 mV), slow-decaying depolarizations (Dilger et al., 2011). These events are also blocked by L-type $\mathrm{Ca}^{2+}$ antagonists (Lo et al., 2002; Dilger et al., 2011). Estimates of retinal convergence were accomplished by generating EPSP/EPSC amplitude by stimulus intensity plots (see also Lo et al., 2002; Jaubert-Miazza et al., 2005; Ziburkus and Guido, 2006; Dilger et al., 2011; Seabrook et al., 2013). These were constructed by first determining the minimum stimulus intensity needed to evoke a postsynaptic response. Once the singlefiber response was determined, current intensity was increased in small increments $(0.5-1.0 \mu \mathrm{A})$ until a response of maximal amplitude was consistently reached. For each stimulus intensity, a minimum of five responses was obtained. A change in amplitude that was equal to or exceeded a value that corresponded to the amplitude of the single-fiber response was used to distinguish one input from another (Dilger et al., 2011; Seabrook et al., 2013).

To examine the spontaneous activity of RGCs, multielectrode array recordings were performed in acutely prepared retinal explants (Demas et al., 2003, 2006). After $1 \mathrm{~h}$ of dark adaptation, and under infrared illumination, mice were deeply anesthetized with isoflurane inhalation and decapitated, and the retina was removed in cooled, oxygenated ACSF, as follows (in mM): $119 \mathrm{NaCl}, 2.5 \mathrm{KCl}, 1.3 \mathrm{MgCl}_{2}, 2.5 \mathrm{CaCl}_{2}, 1.0$ $\mathrm{NaH}_{2} \mathrm{PO}_{4}, 11$ glucose, and 20 HEPES. A piece of retina was placed ganglion cell side down onto a 60-channel MEA amplifier (Multi Channel Systems), which was held in place with a lightly weighted insert filter (Corning), superfused with oxygenated ACSF (1-2 $\mathrm{ml} / \mathrm{min}$ ), and maintained at $31-33^{\circ} \mathrm{C}$. The ITO (indium tin oxide) array electrodes were 30 $\mu \mathrm{m}$ in diameter, arranged on an $8 \times 8$ rectangular grid, with $100 \mu \mathrm{m}$ interelectrode spacing and a $10 \mu \mathrm{m}$ electrode area. The retina was allowed to rest for $1 \mathrm{~h}$ before conducting recordings in complete darkness. Analog data were acquired at $25 \mathrm{kHz} /$ channel. In some instances, the antagonists DNQX (AMPAR; catalog \#2312, Tocris Bioscience), D-APV (NMDAR; catalog \#0106, Tocris Bioscience), and DH $\beta$ E (neuronal $\alpha_{4}$ subunit-containing nicotinic receptor; catalog \#2349, Tocris Bioscience) were bath applied at a concentration of $25 \mu \mathrm{M}$. A threshold of six times the SD of the noise was set for each channel, and $1 \mathrm{~ms}$ of data before a threshold-crossing event and $3 \mathrm{~ms}$ after the threshold event were stored for each waveform. Spike waveforms were then sorted using the MCRack window method, while quantification of wave metrics was performed with Neuroexplorer and custom Matlab software. The burst duration within a wave and the interwave interval was determined using methods described previously (Demas et al., 2003, 2006). Burst duration for a given cell was estimated by finding epochs of high-frequency firing within a wave that conformed to the full-width at half-maximum of its spike train autocorrelogram. The interwave interval was determined by finding local peaks in the population firing and measuring the time be- 
A
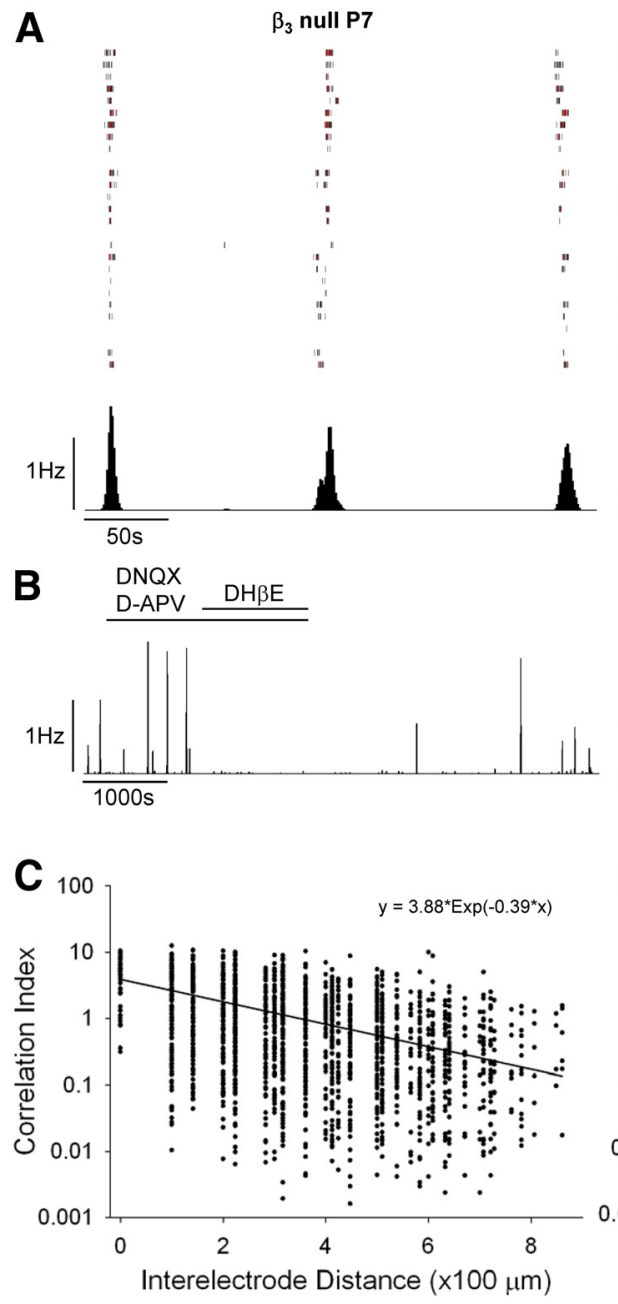
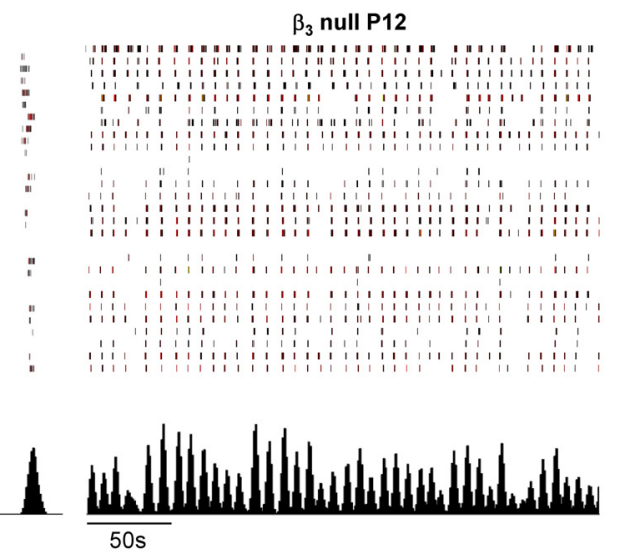

$\underline{\mathrm{DH} \beta E} \quad \underline{\mathrm{D}-\mathrm{APV}} \quad \underline{\mathrm{DNQX}}$

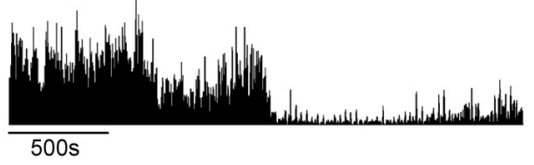

Figure 3. Retinal waves in $\beta_{3}$-null mice. $A$, Rasters depicting spike trains for 30 simultaneously recorded RGCs from $\beta_{3}$-null retinae at P7 and P12 for a period of $300 \mathrm{~s}$. Black vertical lines depict a single spike, and red lines depict 10 spikes. Below each raster is the corresponding histogram (1 s bins) showing the firing rate of the cells recorded above. $\boldsymbol{B}$, Representative response histograms demonstrating the underlying pharmacology of retinal waves. At P7, waves persisted in the presence of the glutamatergic antagonists DNQX and D-APV, but were blocked by the cholinergic antagonist $\mathrm{DH} \beta \mathrm{E}$. At P12, waves continued in the presence of DH $\beta E$, but were blocked by D-APV and DNQX. C, Plots showing correlation indices between pairs of cells (2300 pairs from three mice at P7; 1600 pairs from three mice at P12), with each dot representing one pair, as a function of the estimated distance separating the pair. For each age, the least-squares fit (solid line) and corresponding equation to an exponential decaying function are shown.

tween peaks. The correlation index was computed for pairs of RGCs by counting the spikes from the first spike train that occurred within $50 \mathrm{~ms}$ of each spike in the other spike train (Demas et al., 2006). Counts were normalized by the spike count predicted by a Poisson distribution of the mean firing rate of the first train (Demas et al., 2003).

Anterograde labeling of retinogeniculate projections. To visualize the retinal projections in $\mathrm{dLGN}$, we made eye injections of cholera toxin $\mathrm{B}$ (CTB) conjugated to Alexa Fluor dyes (Jaubert-Miazza et al., 2005; Demas et al., 2006). Mice were anesthetized by isoflurane inhalation or with intraperitoneal injections of ketamine/xylazine $(100 / 10 \mathrm{mg} / \mathrm{kg}$; at $>$ P27). Using a dissecting microscope, the sclera and cornea were pierced with a glass pipette, and excess vitreous was drained. Another pipette, filled with a $1 \%$ solution of a fluorescent conjugate (Alexa Fluor 488 or 594) of CTB (Invitrogen) in distilled water was inserted into the hole made by the first pipette. The pipette containing CTB was attached to a picospritzer and $4-8 \mu \mathrm{l}$ of solution was injected into the eye. After 2-3 d, mice were deeply anesthetized with isoflurane and were transcardially perfused with PBS for 5 min and $4 \%$ paraformaldehyde in $0.1 \mathrm{M}$ phosphate buffer for $25 \mathrm{~min}$. Brains were removed, post-fixed overnight, and sectioned $(70 \mu \mathrm{m})$ in the coronal plane using a vibratome (VT1000S, Leica). Sections containing dLGN were mounted with ProLong Gold
Antifade Reagent (Invitrogen) and visualized with fluorescent microscopy. Images of dLGN were acquired with a Photometrics Coolsnap camera attached to a Nikon Eclipse fluorescence microscope using a $10 \times$ objective. Fluorescent images of labeled sections were acquired and digitized separately $(1300 \times 1030$ pixels/frame) using different filter settings for each dye. To determine the spatial extent of labeled retinal projections in dLGN, gray-scale images were converted into binary images using a threshold that corresponded to a location in the gray-scale histogram where there was a clear distinction between signal and residual background fluorescence (Jaubert-Miazza et al., 2005; for review, see Torborg and Feller, 2005; Demas et al., 2006). Typical threshold levels corresponded to a value of $30-50$ on the gray-scale-normalized range of $0-255$. Using the binarized images, we measured the spatial extent of ipsilateral and contralateral projections by counting the total number of labeled pixels within the boundaries of the dLGN. To determine the extent to which projections from the two eyes overlap, we superimposed the binarized red and green images and counted the pixels that contained both red and green signal fluorescence. The size of ipsilateral, contralateral, and overlapping projections were computed, summed across four to five successive sections through the middle of the dLGN, and expressed as a percentage of the total area of the dLGN. An R analysis, based on the log ratio of pixel intensity, was also used to assess the degree of segregation between crossed and uncrossed projections (Demas et al., 2006).

CREB and phosphorylated CREB immunostaining, and cell fluorescence analysis. Animals were perfused with $4 \%$ paraformaldehyde to preserve the phosphorylated state of CREB (pCREB; Pham et al., 1999, 2001; Krahe et al., 2012). Coronal sections (40 $\mu \mathrm{m}$ thick) containing dLGN were placed in a solution of $2.5 \%$ bovine serum albumin, $0.03 \%$ Triton X-100, and 5\% normal goat serum in PBS for $1 \mathrm{~h}$ at room temperature. The primary antibodies were diluted in blocking solution, and sections were incubated in either rabbit antiCREB (1:2000; Cell Signaling Technology) or rabbit anti-pCREB (1: 800; Cell Signaling Technology) overnight at $4^{\circ} \mathrm{C}$. Sections were then incubated with secondary antibody (Alexa Fluor 488 goat anti-rabbit; 1:250; Invitrogen) in blocking solution at room temperature for $2 \mathrm{~h}$. Sections were placed on slides and mounted with ProLong Gold antifade reagent with DAPI (Invitrogen).

To quantify cellular labeling of total CREB and pCREB, we measured the mean pixel intensity of fluorescence found within the soma of individual dLGN cells (Krahe et al., 2012). We then counted the number of labeled cells found within three to four $100 \times 100 \mu \mathrm{m}^{2}$ regions of dLGN. Cell counts were conducted in a blind fashion using ImageJ software. Only those cells in a well delineated continuous membrane within a given focal plane were included in the analysis. For the fluorescence intensity measurements, a threshold was set using MetaMorph software so that there was a clear distinction between signal and residual background fluorescence (Krahe et al., 2012).

\section{Results}

Postsynaptic activity in WT and $\boldsymbol{\beta}_{3}$-null dLGN cells

Figure $1 A$ provides examples of whole-cell dLGN recordings obtained in acutely prepared thalamic slices from WT and $\beta_{3}$-null 

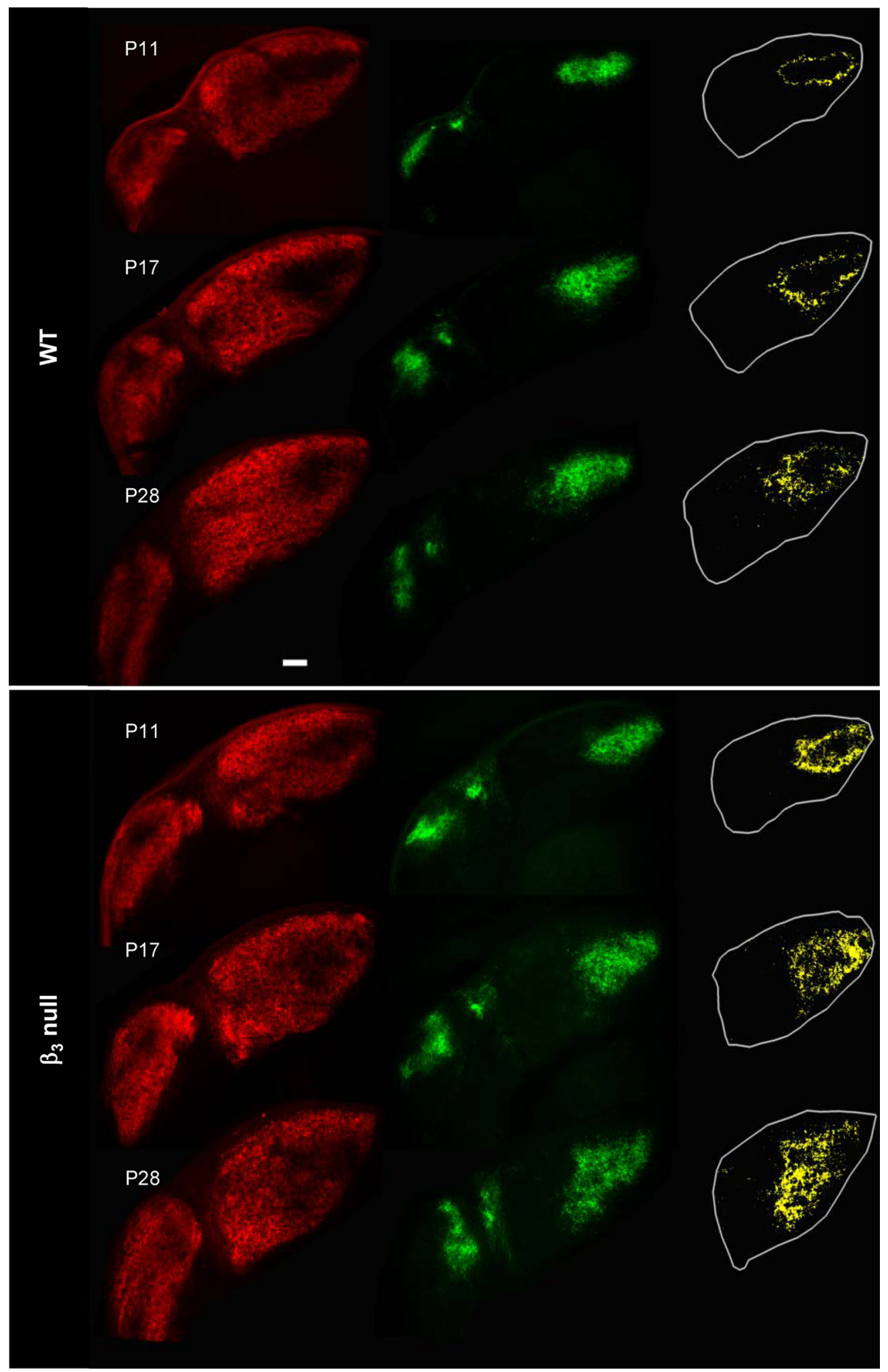

Figure 4. Eye-specific patterning in WT and $\beta_{3}$-null mice. Representative coronal sections from WT and $\beta_{3}$-null dLGNs at P11,P17, and P28. Shown are the retinal terminal fields for contralateral (Alexa Fluor 594, red) and ipsilateral (Alexa Fluor 488, green) eyes. Binarized representations depict the degree of overlap (yellow) between the projections from the two eyes, with the dLGN outlined in white. Scale bar, $100 \mu \mathrm{m}$.

dLGN cells, showing the postsynaptic activity evoked by OT stimulation. As shown previously in WT mice younger than P14, plateau potentials are readily evoked either with single (18 of 38 cells) or repetitive stimulation ( 21 of 31 cells for 50 and $100 \mathrm{~Hz}$; Fig. 1B; see also Lo et al., 2002; Jaubert-Miazza et al., 2005; data are as published in Dilger et al., 2011). Typically, these events take the form of sustained, high-amplitude, slow-decaying depolarizations (Fig. $1 A$, top). By contrast, in $\beta_{3}$-null dLGN cells, even though OT stimulation can readily evoke EPSPs (Fig. 1A, bottom), plateaus were never observed with a single pulse ( 0 of 26 

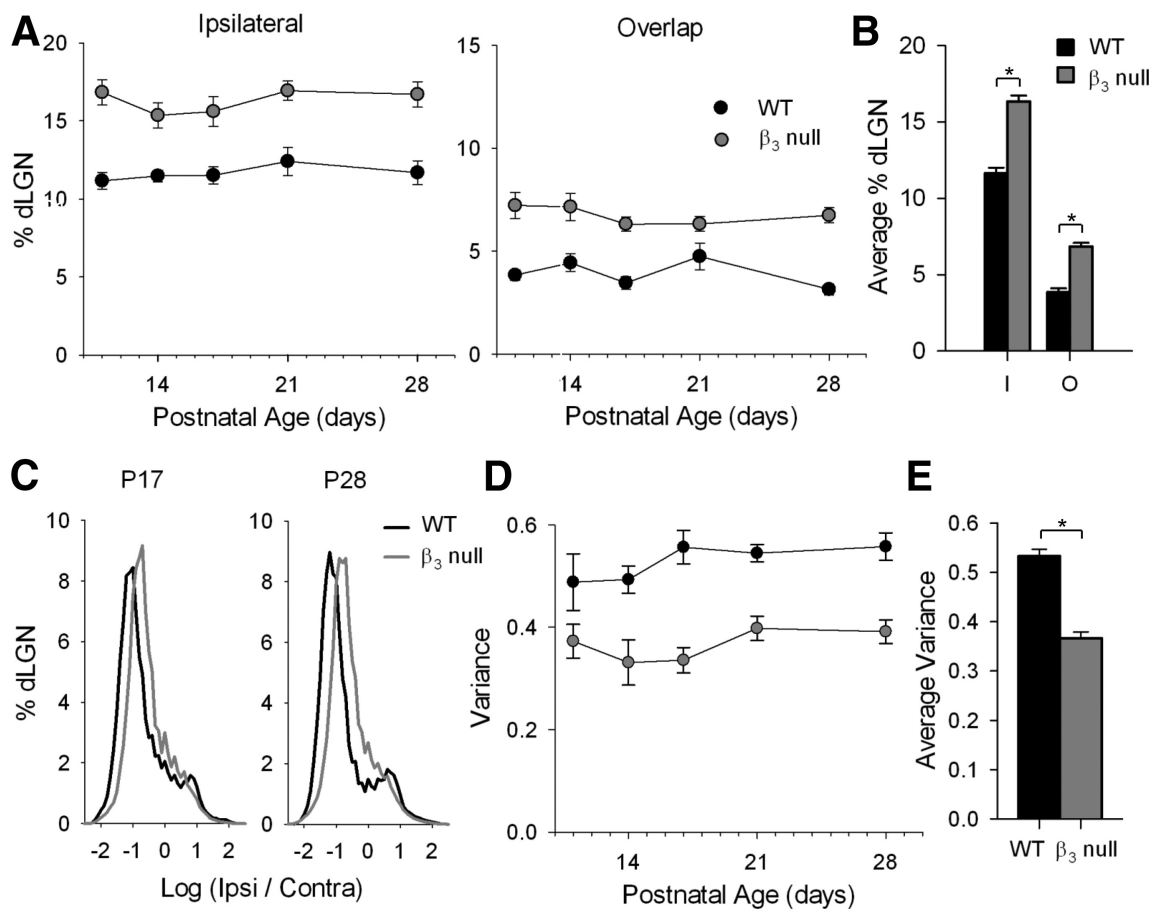

E

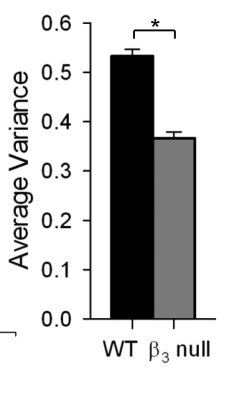

Figure 5. Quantification of eye-specific patterning in WT and $\beta_{3}$-null mice. A, Plots showing the percentage of the area of dLGN occupied by projections from the ipsilateral eye (left) and the overlap between the projections from the two eyes (right) in WT (black) and $\beta_{3}$-null (gray) mice as a function of postnatal day (P11, P14, P17, P21, and P28). Each point represents the mean and SEM for animals at that age. $\boldsymbol{B}$, Summary graph showing the mean and SEM of the spatial extent of ipsilateral and overlapping projections across age for WT and $\beta_{3}$-null mice. $C$, Averaged distribution of the log ratio ( $R$ value) for pixel intensities of contralateral and ipsilateral eye projections at P17 and P28 for WT and $\beta_{3}$-null mice. D, Plot showing the mean and SEM of variance for WT and $\beta_{3}$-null mice as a function of age. $\boldsymbol{E}$, Summary graph showing the mean and SEM of variance across age for WT and $\beta_{3}$-null mice. ${ }^{*} p<0.0001$, WT vs $\beta_{3}$-null. $\beta_{3}$-null and WT dLGNs: $5-11$ at each age.
The absence or defects in plateau activity in $\beta_{3}$-null dLGN cells does not appear to be due to reduced glutamatergic drive at retinogeniculate synapses. Representative examples at $\mathrm{P} 10$ and $\mathrm{P} 15$ reveal that a strong single pulse delivered to OT evoked large EPSCs, with AMPAR and NMDAR components that were indistinguishable from WT dLGN cells (Fig. 2A). When measured at P9-P11 and P15-P17, the maximal amplitude of AMPAR and NMDAR currents in $\beta_{3}$-null dLGN cells was similar to that of WT dLGN cells (Fig. $2 B$; one-way ANOVA, $F=0.260 ; p=0.1$ ). The age-related maturation of these excitatory currents (Liu and Chen, 2008) was also normal (Fig. 2C-E). The relative strength of AMPAR currents compared with that of NMDAR currents increased with age (Fig. 2C; multivariate ANOVA, $F=67.09 ; p<0.001)$. Within each age group, the ratios of AMPAR to NMDAR in WT and $\beta_{3}$-null dLGN cells were not significantly different from each other (multivariate ANOVA: $F=0.15 ; p=0.7$ ). Furthermore, NMDAR decay decreased with age in both WT and $\beta_{3}$-null dLGN cells (Fig. 2D,E; multivariate ANOVA, $F=$ 92.03; $p<0.001)$. Additionally, within each age group WT and $\beta_{3}$-null dLGN cells were not significantly different from each other (multivariate ANOVA: $F=2.77 ; p=0.1)$. cells) and were rare even when rates as high as 50 ( 2 of 26 cells) or $100 \mathrm{~Hz}$ are used ( 10 of 26 cells; Fig. $1 B$; data are as published in Dilger et al., 2011; $\chi^{2}$ test, $p<0.001$ for all WT vs $\beta_{3}$-null dLGN cell comparisons). These events, while rare in $\beta_{3}$-null dLGN cells, were blocked by the L-type antagonist nimodipine $(n=3$ cells; see also Lo et al., 2002; Dilger et al., 2011). As shown in Figure 1C, bath application of nimodipine abolished the plateau-like depolarization, leaving underlying EPSP activity intact. Subsequent application of the NMDA antagonist APV led to a further reduction, indicating that high-frequency OT stimulation evokes robust NMDA-mediated postsynaptic activity, an event that contributes to the activation of high-threshold L-type $\mathrm{Ca}^{2+}$ channels (Lo et al., 2002; Dilger et al., 2011).

To determine whether the few plateaus that are evoked in $\beta_{3}$-null dLGN cells are similar to those evoked in WT dLGN cells, we analyzed the amplitude as well as the rates of rise and decay of plateau activity evoked at $100 \mathrm{~Hz}$ OT stimulation. Compared with WT dLGN cells, mean peak amplitude (as measured from baseline to the trough of inactivating $\mathrm{Na}^{+}$spikes) in $\beta_{3}$-null dLGN cells was significantly smaller (Fig. $1 A$; WT cells, $51.9 \pm 0.8$ $\mathrm{mV}$; $\beta_{3}$-null cells, $42.2 \pm 1.6 \mathrm{mV}$; Student's $t$ test, $p<0.001$ ). Plateaus in $\beta_{3}$-null dLGN cells had significantly slower rise times (measured as the slope of a linear best-fit line fit to the first $50 \mathrm{~ms}$ of the response) than WT dLGN cells (Fig. 1D, top; Student's $t$ test, $p<0.001$ ). The decay of $\beta_{3}$-null dLGN cell plateaus (measured as the slope of a single-parameter curve, fit to the $50 \mathrm{~ms}$ after the inactivating $\mathrm{Na}^{+}$spikes) were also significantly slower than that of WT dLGN cells (Fig. 1D, bottom; Student's $t$ test, $p<$ $0.001)$.
Spontaneous retinal activity in WT and $\boldsymbol{\beta}_{3}$-null dLGN cells While the overall structural and functional organization of adult $\beta_{3}$-null mouse retinae is reported to be normal (Ball et al., 2002), the patterns of spontaneous retinal activity before eye opening remain unexplored. To address this, we performed in vitro multielectrode array recordings of retinal explants from $\beta_{3}$-null and WT dLGN cells at P7 and P12. The properties of retinal waves recorded in $\beta_{3}$-null dLGN cells were indistinguishable from those of WT dLGN cells (Table 1; see also Demas et al., 2003, 2006). Examples of recordings from $\beta_{3}$-null mouse retinae are shown in Figure 3. At P7, $\beta_{3}$-null RGCs fired bursts of action potentials that lasted $\sim 2 \mathrm{~s}$ followed by quiescent periods of $90-150 \mathrm{~s}$ (Fig. $3 A$ ). At this age, bath application of glutamatergic antagonists DNQX and D-APV had no effect on spontaneous activity, while the cholinergic antagonist $\mathrm{DH} \beta \mathrm{E}$ eliminated waves (Fig. $3 B$ ). By $\mathrm{P} 12$, periodic activity persisted but, as reported in WT retinae (Demas et al., 2003, 2006; Maccione et al., 2014), burst duration within a wave and the interwave interval became shorter (Table 1; Fig. 3A). At this age, and in both WT (data not shown; but see Demas et al., 2003, 2006) and $\beta_{3}$-null RGCs, DH $\beta$ E had no effect on wave activity, while the application of D-APV reduced waves, and DNQX subsequently eliminated them (Fig. 3B). These pharmacological effects reflect the age-related shift from stage II cholinergic to stage III glutamatergic wave activity (Demas et al., 2003; Torborg and Feller, 2005).

We also measured the spatial-temporal correlations of activity among neighboring $\beta_{3}$-null RGCs. The degree to which developing RGCs fire together depends upon the distance separating the two cells (Demas et al., 2003). This was assessed for pairs of 
cells by computing a correlation index as a function of the estimated distance between them, as measured by the position of their recording electrode (Demas et al., 2003, 2006). In $\beta_{3}$-null RGCs at both P7 and P12, the correlation index between the firing time of neighboring RGCs decreased as a function of intercell distances (Fig. 3C). Additionally, at P12 we calculated the coherence of cell pairs to determine whether their activity occurs regularly at a particular frequency. At P12, the mean coherence was $0.15 \mathrm{~Hz}$, corresponding closely to the frequency measured in our WT mice $(0.14 \mathrm{~Hz})$ and to values typically reported for this age by others (Demas et al., 2003, 2006; Maccione et al., 2014).

\section{Retinogeniculate refinement in WT and $\boldsymbol{\beta}_{3}$-null mice}

To determine whether the disruption in plateau activity in $\beta_{3}$-null mice affects eye-specific segregation in dLGN, we made eye injections of CTB conjugated to two different fluorophores. This allows for the simultaneous visualization of terminal domains occupied by contralateral and ipsilateral projections, as well as the overlap between them (Jaubert-Miazza et al., 2005; Demas et al., 2006). Examples of the labeling pattern in WT and $\beta_{3}$-null mice at different ages are shown in Figure 4. In WT mice, by P11 the regions of dLGN occupied by contralateral and ipsilateral projections were well defined and showed little overlap. Ipsilateral projections were confined to a small patch in the dorsal-medial region of the dLGN. However, in $\beta_{3}$-null mice ipsilateral domains were expanded, particularly along the ventral-medial aspect, and even as late as P28. Estimates of spatial extent revealed that both the ipsilateral patch as well as the degree of overlap between the projections from each eye were significantly larger in $\beta_{3}$-null mice than in WT mice (Fig. $5 A$; univariate ANOVAs: $F=71.71$ for ipsilateral patch; $F=68.66$ for overlap; $p<0.001$ for both variables). For both $\beta_{3}$-null and WT mice, values of spatial extent remained relatively stable across the ages studied (univariate ANOVAs: $F=0.67$ for ipsilateral; $F=1.02$ for overlap; $p>0.4$ for both variables). Thus, when values were combined across age, those for $\beta_{3}$-null mice were significantly larger than those for WT mice (Fig. $5 B$; Student's $t$ tests; $p<0.0001$ for both comparisons). Eye-specific segregation can also be quantified by analyzing the fluorescent intensity of individual pixels (Torborg and Feller, 2004; Jaubert-Miazza et al., 2005; Demas et al., 2006). For each pixel in a labeled section of dLGN, we calculated the $R$ value, the logarithm of the ratio of fluorescent intensities for ipsilateral $\left(F_{I}\right)$ and contralateral $\left(F_{C}\right)$ eye projections $\left[r=\log \left(F_{I} / F_{C}\right)\right]$. Averaged histograms of the $R$ values for labeled sections of WT and $\beta_{3}$-null mice at P17 and P28 are shown in Figure 5C. As expected, WT distributions were wide and had large variances, features that reflect a high degree of segregation (Jaubert-Miazza et al., 2005; Demas et al., 2006). By contrast, $\beta_{3}$-null mouse distributions re-
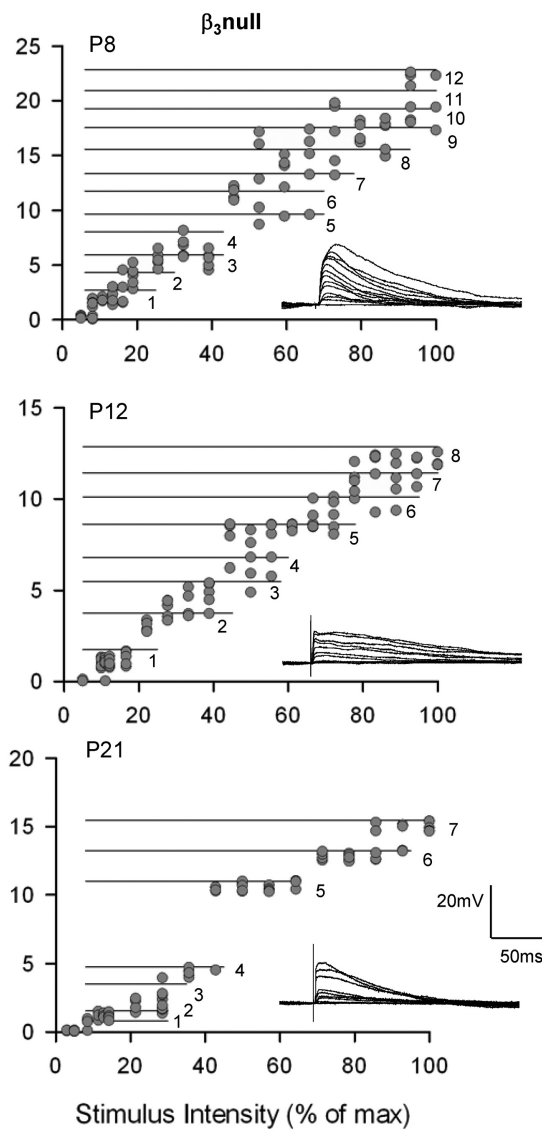

Stimulus Intensity (\% of max)

Figure 6. Synaptic responses and stimulus intensity plots for WT and $\beta_{3}$-null dLGN cells. Representative examples of retinal convergence at different postnatal ages in WT (left) and $\beta_{3}$-null (right) dLGN cells. For each cell, synaptic responses are evoked by intensity. In WT cells, response profiles changed with age, from a graded function (at P7), which reflects high levels of convergence, to a step-like one (at P21), which illustrates less convergence and few inputs. In $\beta_{3}$-null mice, dLGN cells continued to show graded response profiles and high levels of convergence. Voltage responses were recorded at $-60 \mathrm{mV}$. max, Maximum.

flected a more diffuse state and were narrow with significantly smaller variances (Fig. 5D; univariate ANOVA: $F=76.77$; $p<$ $0.001)$. For both $\beta_{3}$-null and WT mice, the variance remained stable across the ages studied (univariate ANOVA: $F=1.62 ; p=$ 0.19 ), and when values were combined across age, those for $\beta_{3}$ null mice were significantly smaller than those for WT mice (Fig. $5 E$; Student's $t$ test; $p<0.0001)$.

Finally, we asked whether the diffuse projections noted in $\beta_{3}$-null mice were accompanied by abnormal patterns of retinal connectivity. To accomplish this, we obtained estimates of retinal convergence by examining the synaptic responses of dLGN cells evoked by systematic changes in the intensity of OT stimulation. Figure 6 shows examples of the synaptic responses for WT and $\beta_{3}$-null dLGN cells evoked at progressively higher levels of stimulus intensity. Estimates of retinal convergence for individual dLGN cells can be derived from their stimulus intensity by response amplitude plots (Lo et al., 2002; Jaubert-Miazza et al., 2005; Ziburkus and Guido, 2006; Dilger et al., 2011; Seabrook et al., 2013). To delineate each step, we adopted criteria based on the amplitude of the single-fiber response (see Materials and Methods). In WT mice at P7 (Fig. 6), increases in stimulus intensity evoked a progressive and graded increase in EPSP amplitude. Such a response function reflects high levels of convergence. By 
A
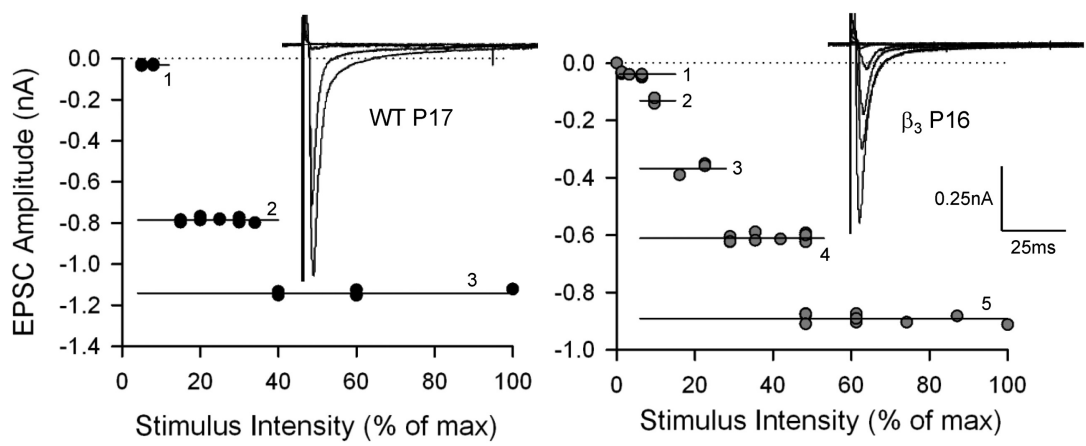

B
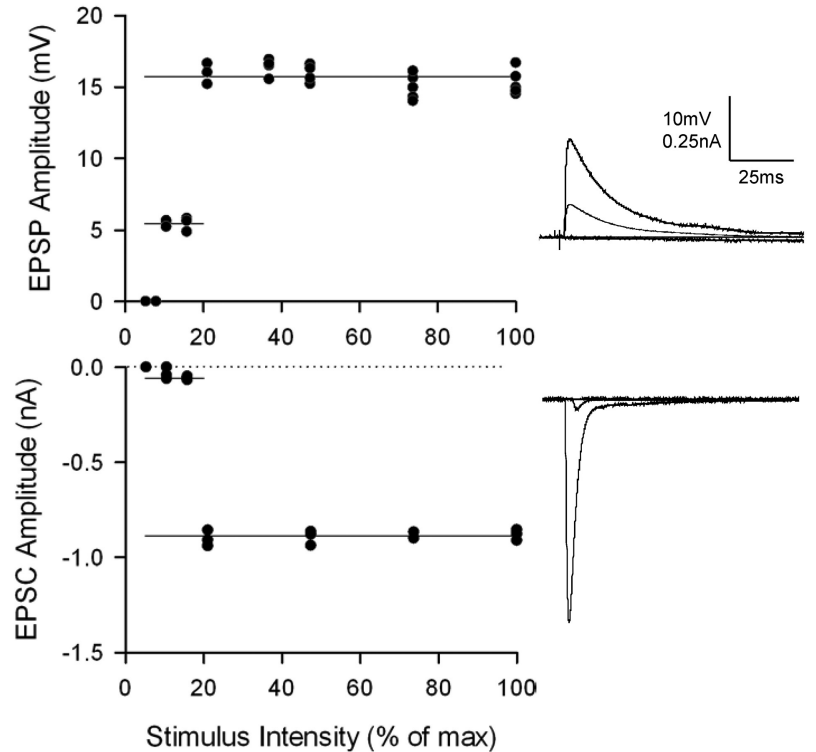

C

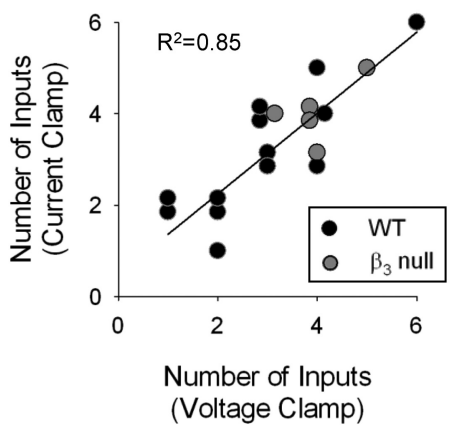

Figure 7. Estimates of retinal convergence obtained in current-clamp and voltage-clamp modes. $\boldsymbol{A}$, Synaptic responses recorded in voltage clamp mode from a WT P17 cell and a $\beta_{3}$-null P16 cell that were evoked by progressive changes in stimulus intensity. Accompanying each set of responses is the corresponding stimulus intensity by amplitude plot, along with the estimates of retinal convergence, as in Figure 5. B, Representative responses from a single WT cell recorded in current-clamp mode (top) as well as voltage-clamp mode (bottom). Both modes yielded the same number (two) of inputs. C, Plot showing the correlation between number of inputs estimated for a given cell recorded in current-clamp and voltage-clamp modes. Each dot represents a single cell from a WT (black) or $\beta_{3}$-null (gray) mouse. The solid line represents the linear fit $(p<0.001)$. Comparable estimates were obtained in either mode. Responses were recorded at $-70 \mathrm{mV}$. $\beta_{3}$-null (WT) cells: 5 (13). max, Maximum.

P21, response profiles became more step like, indicating that cells received far fewer inputs. By contrast, in $\beta_{3}$-null cells, responses remained graded even at late postnatal ages, suggesting that a high degree of retinal convergence was maintained.

It is important to note that, whether in current-clamp or voltage-clamp mode, estimates of retinal convergence obtained in the manner described above are in accord with those reported previously by our laboratory (Lo et al., 2002; Jaubert-Miazza et al., 2005; Ziburkus and Guido, 2006; Dilger et al., 2011) and other laboratories (Chen and Regehr, 2000; Hooks and Chen, 2006; Stevens et al., 2007). Figure $7 A$ depicts EPSC amplitude by stimulus plots recorded in voltageclamp mode with profiles that matched those obtained in current-clamp mode (Fig. 6). To further illustrate this point, we derived estimates for 18 cells recorded in both current-clamp and voltage-clamp modes (Fig. $7 B, C$ ). For both WT and $\beta_{3}$ null mice, similar estimates of retinal convergence were obtained in either mode (Fig. $6 C ; R^{2}=0.73 ; p<0.001$ ).

The input/output relations of retinal convergence are summarized in Figure $8 A$, which plots estimates of retinal inputs for all cells recorded in WT and $\beta_{3}$-null mice. As expected in WT mice, there was an age-related decrease in retinal convergence such that at early ages cells received as many as $6-10$ inputs, but by P18 received only 1-3 inputs remained. However, $\beta_{3}$-null dLGN cells had more inputs at early ages and underwent far less pruning such that, even at P31, some cells had as many as 10 inputs. To further illustrate these differences, we computed a convergence ratio $(\mathrm{CR})$ by dividing the total number of inputs $(I)$ by the total number of cells $(N)$ recorded at a given age $(\mathrm{Px})$ $\left(\mathrm{CR}_{\mathrm{Px}}=\Sigma I_{\mathrm{Px}} / \Sigma N_{\mathrm{Px}}\right)$. When these values are plotted as a function of postnatal age (Fig. $8 B$ ), the CR decreased in both WT and $\beta_{3}$-null cells. However, cells from $\beta_{3}$ null mice at older ages retained much higher values than those from age-matched WT mice, and had a CR distribution that was significantly different (KolmogorovSmirnov test: $Z=1.524 ; p<0.02$ ). This is best illustrated at $\mathrm{P} 18$ and older, where in WT mice $C R$ values were $<2$, but in $\beta_{3}$-null mice, they were 3-5.

\section{CREB and pCREB immunostaining of}

WT and $\boldsymbol{\beta}_{3}$-null cells

To address a potential $\mathrm{Ca}^{2+}$-related signaling mechanism that underlies the breakdown in refinement in $\beta_{3}$-null mice, we examined the expression of total CREB, as well as pCREB. Since CREB levels are reported to peak at relatively early postnatal ages (Pham et al., 2001; Krahe et al., 2012), we immunostained dLGN cells for CREB and pCREB at P10 (Fig. 9A). Both WT and $\beta_{3}$-null dLGN cells showed robust cellular labeling for total CREB, with no significant differences in either the pixel intensity or number of stained cells (Fig. 9B; Student's two-tailed $t$ tests; $p>$ $0.28)$. However, while the pCREB staining in WT cells was also quite strong, it was markedly decreased in $\beta_{3}$-null cells (Fig. $9 A$ ). For pCREB, the mean pixel intensity and cell count was significantly reduced in $\beta_{3}$-null cells compared with WT cells (Fig. 9B; Student's two-tailed $t$ test, $p<0.05$ for both comparisons). 


\section{Discussion}

Our results in $\beta_{3}$-null mice indicate that L-type $\mathrm{Ca}^{2+}$ channel activity in the form of plateau potentials plays an important role in the refinement of the retinogeniculate pathway. These mice show a greatly reduced expression of L-type channels and almost a complete loss of plateau activity in dLGN (Dilger et al., 2011). Here, we also show that the few plateaus evoked with high rates of stimulation were reduced in amplitude, and had slower rise and longer decay times than in WT mice. These defects are likely due to the targeted deletion of the $\beta_{3}$ subunit, an element that is needed for proper channel kinetics, assembly, and membrane insertion (Namkung et al., 1998; Bichet et al., 2000; Murakami et al., 2002; for review, see Dolphin, 2003; Shiraiwa et al., 2007).

The paucity of plateau activity in $\beta_{3^{-}}$ null mice was accompanied by a breakdown in retinogeniculate refinement. Eye-specific domains in dLGN do not develop properly. $\beta_{3}$-null mice maintained greatly expanded ipsilateral eye terminal fields with a spatial extent that overlapped with those originating from the contralateral eye. The pruning of retinal connections onto relay cells was also compromised, with dLGN cells typically having a higher degree of retinal convergence than age-matched dLGN cells from WT mice. These defects in refinement could not be attributed to a reduction in presynaptic or postsynaptic excitatory drive. Both spontaneous retinal activity and glutamatergic synaptic responses in dLGN cells were normal. $\beta_{3}$-null mice displayed stage II and III waves that were indistinguishable from those of WT mice. In dLGN, the composition of retinally evoked EPSCs was similar to that of age-matched WT mice. The peak amplitude of $\beta_{3}$-null mouse excitatory currents was similar to that of WT mice. The reported changes in the maturation of these currents were also observed (Liu and Chen, 2008). Both the ratio of AMPAR to NMDAR currents, as well as NMDAR decay times matured in ways indistinguishable from those of WT mice.

Perhaps the persistence of these features could help explain why retinogeniculate refinement in $\beta_{3}$-null mice, while impaired, was not completely absent. At late postnatal ages, both the spatial extent of overlapping inputs and the degree of retinal convergence do not reflect the highly diffuse state noted at very early postnatal ages (Chen and Regehr, 2000; Jaubert-Miazza et al., 2005; for review, see Hong and Chen, 2011). In fact, the degree of overlapping inputs from the two eyes, while comparable to some mouse models that disturb stage III retinal waves (Demas et al., 2006) or lead to reduced levels of CREB (Pham et al., 2001) or adenylate cyclase 1 signaling (Dhande et al., 2012), is not as high as the degree of overlapping inputs seen in models associated with a breakdown in stage II retinal waves (Muir-Robinson et al., 2002) or other mutants that compromise the MHC1 system (Dawtani et al., 2009; Lee et al., 2014) or the classic complement signaling cascade (Stevens et al., 2007; but see Shafer et al., 2012). One possibility for this is that retinal waves in the $\beta_{3}$-null mice still drive NMDARs in dLGN to provide some amount of $\mathrm{Ca}^{2}$ influx, which in turn could trigger plasticity-related signaling cascades associated with the CREB pathway. Our pCREB immunostaining supports this notion, since in $\beta_{3}$-null dLGN pCREB labeling was present, though greatly reduced. At early ages, NMDAR currents dominate excitatory transmission at the retinogeniculate synapse, and their subunit composition seems to favor a relaxed voltage dependency and longer decay times, thereby allowing for more $\mathrm{Ca}^{2+}$ influx (Liu and Chen, 2008). Thus, early NMDAR activity, while not sufficient by itself to drive retinogeniculate refinement (Hahm et al., 1991) could play a contributing role.

How then can plateaus and L-type channel activity contribute to activity-dependent refinement in dLGN? Our in vitro recordings from WT suggest that summating postsynaptic responses associated with retinal waves provides the requisite excitatory drive to trigger plateau activity in dLGN cells (Lo et al., 2002; Dilger et al., 2011). Because of their close proximity to retinal synapses on the soma and proximal regions of dendrites (Budde et al., 1998; Bickford et al., 2010; Dilger et al., 2011), L-type channels are well positioned to ensure coincident activation with retinally mediated events. The functional patterns of connectivity (e.g., a high degree of retinal convergence and a lack of feedforward inhibition) as well as the high density of L-type channels noted at early ages further ensure a high rate of coordinated activation (Dilger et al., 2011). 
A
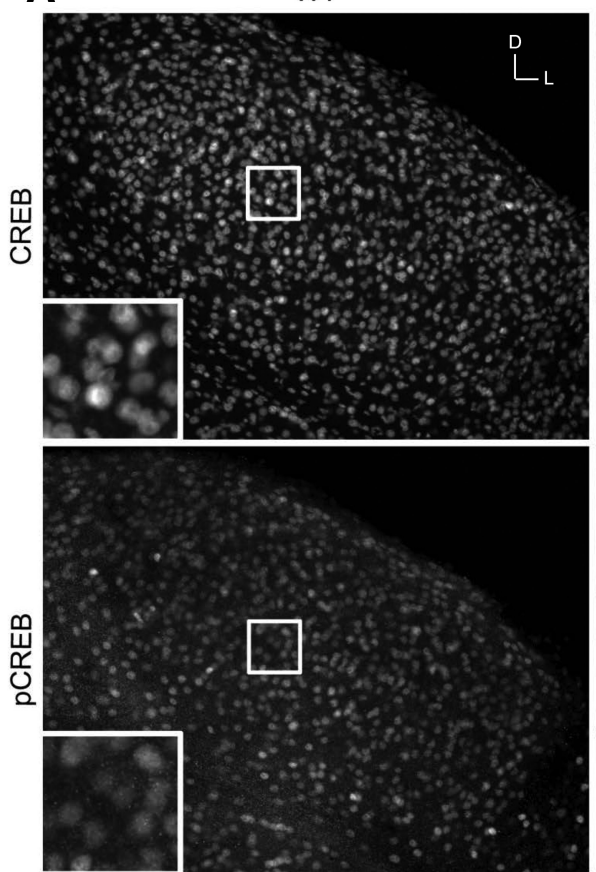

B

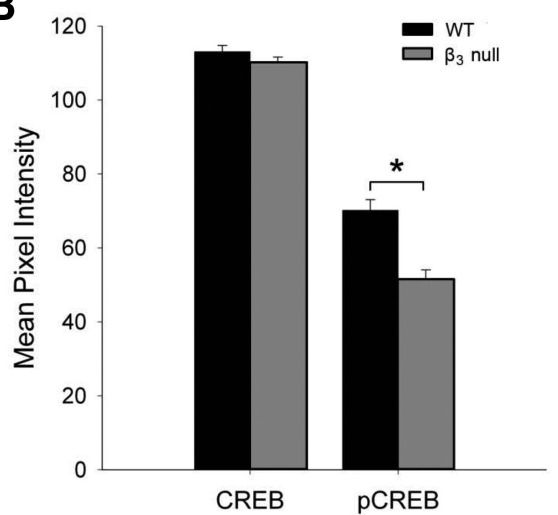

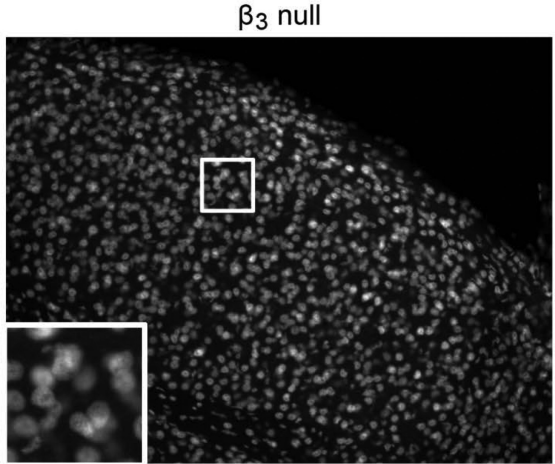
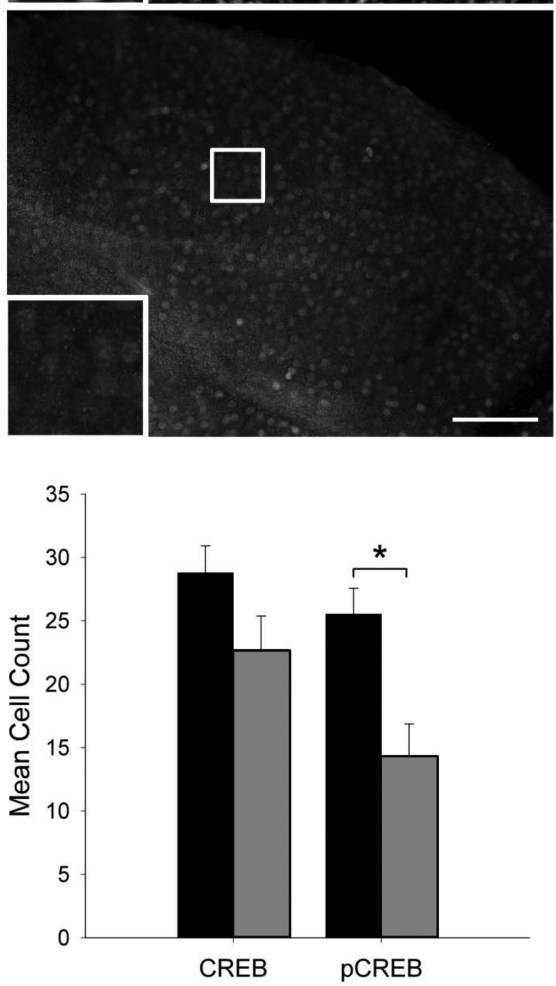

Figure 9. CREB and pCREB labeling in WT and $\beta_{3}$-null dLGN cells. $A$, Fluorescent immunostaining for total CREB (top) and pCREB (bottom) in 40- $\mu \mathrm{m}$-thick coronal sections of P10 WT (left) and $\beta_{3}$-null (right) dLGN cells. Boxes indicate the location of the magnified view, seen in the inset in each image. Scale bar: low magnification, $100 \mu \mathrm{m}$; high magnification, $40 \mu \mathrm{m}$. D, Dorsal; L, lateral. $\boldsymbol{B}$, Plots show the mean and SEM of CREB and pCREB pixel intensity of fluorescence (left) and mean cell count (right) in three to four $100 \mu \mathrm{m} \times 100 \mu \mathrm{m}$ sections of each dLGN in WT (black) and $\beta_{3}$-null (gray) mice. ${ }^{*} p<0.05$, comparisons between genotypes. $\beta_{3}$-null (WT) dLGN: CREB, 12 (11); pCREB, 10 (10) from 6 mice.

It is important to note that our experiments do not provide a direct test linking the low expression of pCREB to the absence of plateaus and the breakdown in refinement. However, there is strong convergent evidence in support of such a relationship. The activity-dependent influx of $\mathrm{Ca}^{2+}$ via L-type channels has been linked to several forms of synaptic plasticity and related gene transcription (for review, see Greer and Greenberg, 2008). A likely candidate that has been implicated in retinogeniculate refinement involves the CREB pathway. CREB is developmentally regulated in $\mathrm{dLGN}$, with expression levels peaking during the time of retinogeniculate refinement (Pham et al., 2001; Krahe et al., 2012), and mutant mice with low levels of CREB fail to establish segregated eye-specific domains (Pham et al., 2001). The reduced L-type channel activity noted in the $\beta_{3}$-null mice could also manifest as a change in CREB activation (Mermelstein et al., 2000; Dolmetsch et al., 2001; for review, see Morad and Soldatov, 2005). The CREB and pCREB immunostaining in the current

study further supports a role for L-type $\mathrm{Ca}^{2+}$-activated CREB in retinogeniculate refinement. Although in dLGN $\beta_{3}$-null mice appear to have normal CREB levels, the lack of L-type plateau potentials and the resulting decreased $\mathrm{Ca}^{2+}$ influx reduces CREB phosphorylation, thereby limiting CREB-activated gene transcription and thus leading to an impairment in refinement.

How L-type activity translates into synapse-specific retention and elimination along the dendrites of relay cells, or whether other contributing elements can in part, compensate for the diminished capacity of L-type activity in $\beta_{3}$-null mice remain open to investigation. Nonetheless, our results suggest that L-type plateaus play an important role in the activity-dependent refinement of retinogeniculate connections, and that a perturbation of such postsynaptic activity leads to a breakdown in remodeling.

\section{References}

Ball SL, Powers PA, Shin HS, Morgans CW, Peachey NS, Gregg RG (2002) Role of the beta(2) subunit of voltage-dependent calcium channels in the retinal outer plexiform layer. Invest Ophthalmol Vis Sci 43:1595-1603. Medline

Bichet D, Cornet V, Geib S, Carlier E, Volsen S, Hoshi T, Mori Y, De Waard M (2000) The I-II loop of the Ca2 + channel alphal subunit contains an endoplasmic reticulum retention signal antagonized by the beta subunit. Neuron 25:177-190. CrossRef Medline

Bickford ME, Slusarczyk A, Dilger EK, Krahe TE, Kucuk C, Guido W (2010) Synaptic development of the mouse dorsal lateral geniculate nucleus. J Comp Neurol 518:622-635. CrossRef Medline

Budde T, Munsch T, Pape HC (1998) Distribution of L-type calcium channels in rat thalamic neurones. Eur J Neurosci 10:586-597. CrossRef Medline

Chen C, Regehr WG (2000) Developmental remodeling of the retinogeniculate synapse. Neuron 28:955-966. CrossRef Medline

Cohen S, Greenberg ME (2008) Communication between the synapse and the nucleus in neuronal development, plasticity, and disease. Annu Rev Cell Dev Biol 24:183-209. CrossRef Medline

Datwani A, McConnell MJ, Kanold PO, Micheva KD, Busse B, Shamloo M, Smith SJ, Shatz CJ (2009) Classical MHC1 molecules regulate retinogeniculate refinement and limit ocular dominance plasticity. Neuron 64: 463-470. CrossRef Medline

Demas J, Eglen SJ, Wong RO (2003) Developmental loss of synchronous spontaneous activity in the mouse retina is independent of visual experience. J Neurosci 23:2851-2860. Medline

Demas J, Sagdullaev BT, Green E, Jaubert-Miazza L, McCall MA, Gregg RG, Wong RO, Guido W (2006) Failure to maintain eye-specific segregation in nob, a mutant with abnormally patterned retinal activity. Neuron 50: 247-259. CrossRef Medline

Dhande OS, Bhatt S, Anishchenko A, Elstrott J, Iwasato T, Swindell EC, Xu HP, Jamrich M, Itohara S, Feller MB, Crair MC (2012) Role of adenylate cyclase 1 in retinofugal map development. J Comp Neurol 520:15621583. CrossRef Medline

Dilger EK, Shin HS, Guido W (2011) Requirements for synaptically evoked 
plateau potentials in relay cells of the dorsal lateral geniculate nucleus of the mouse. J Physiol 589:919-937. CrossRef Medline

Dolmetsch RE, Pajvani U, Fife K, Spotts JM, Greenberg ME (2001) Signaling to the nucleus by an L-type calcium channel-calmodulin complex through the MAP kinase pathway. Science 294:333-339. CrossRef Medline

Dolphin AC (2003) Beta subunits of voltage-gated calcium channels. J Bioenerg Biomembr 35:599-620. CrossRef Medline

Goodman CS, Shatz CJ (1993) Developmental mechanisms that generate precise patterns of neuronal connectivity. Cell 72:77-98. CrossRef Medline

Greer PL, Greenberg ME (2008) From synapse to nucleus: calciumdependent gene transcription in the control of synapse development and function. Neuron 59:846-860. CrossRef Medline

Guido W (2008) Refinement of the retinogeniculate pathway. J Physiol 586: 4357-4362. CrossRef Medline

Hahm JO, Langdon RB, Sur M (1991) Disruption of retinogeniculate afferent segregation by antagonists to NMDA receptors. Nature 351:568 -570 . CrossRef Medline

Hong YK, Chen C (2011) Wiring and rewiring of the retinogeniculate synapse. Curr Opin Neurobiol 21:228-237. CrossRef Medline

Hooks BM, Chen C (2006) Distinct roles for spontaneous and visual activity in remodeling of the retinogeniculate synapse. Neuron 52:281-291. CrossRef Medline

Huberman AD, Feller MB, Chapman B (2008) Mechanisms underlying development of visual maps and receptive fields. Annu Rev Neurosci 31: 479-509. CrossRef Medline

Jaubert-Miazza L, Green E, Lo FS, Bui K, Mills J, Guido W (2005) Structural and functional composition of the developing retinogeniculate pathway in the mouse. Vis Neurosci 22:661-676. CrossRef Medline

Kornhauser JM, Cowan CW, Shaywitz AJ, Dolmetsch RE, Griffith EC, Hu LS, Haddad C, Xia Z, Greenberg ME (2002) CREB transcriptional activity in neurons is regulated by multiple, calcium-specific phosphorylation events. Neuron 34:221-233. CrossRef Medline

Krahe TE, Seabrook TA, Chen CK, Fox MA, Guido W (2012) Modulation of CREB in the dorsal lateral geniculate nucleus of dark-reared mice. Neural Plast 2012:426437. CrossRef Medline

Lee H, Brott BK, Kirkby LA, Adelson JD, Cheng S, Feller MB, Datwani A, Shatz CJ (2014) Synapse elimination and learning rules co-regulated by MHC 1 H2-Db. Nature 509:195-200. CrossRef Medline

Liu X, Chen C (2008) Different roles for AMPA and NMDA receptors in transmission at the immature retinogeniculate synapse. J Neurophysiol 99:629-643. CrossRef Medline

Lo FS, Ziburkus J, Guido W (2002) Synaptic mechanisms regulating the activation of a $\mathrm{Ca}(2+)$-mediated plateau potential in developing relay cells of the LGN. J Neurophysiol 87:1175-1185. Medline

Maccione A, Hennig MH, Gandolfo M, Muthmann O, van Coppenhagen J, Eglen SJ, Berdondini L, Sernagor E (2014) Following the ontogeny of retinal waves: pan-retinal recordings of population dynamics in the neonatal mouse. J Physiol 592:1545-1563. CrossRef Medline

Mermelstein PG, Bito H, Deisseroth K, Tsien RW (2000) Critical dependence of cAMP response element-binding protein phosphorylation on L-type calcium channels supports a selective response to EPSPs in preference to action potentials. J Neurosci 20:266-273. Medline

Mooney R, Penn AA, Gallego R, Shatz CJ (1996) Thalamic relay of spontaneous retinal activity prior to vision. Neuron 17:863-874. CrossRef Medline

Morad M, Soldatov N (2005) Calcium channel inactivation: possible role in signal transduction and Ca2+ signaling. Cell Calcium 38:223-231. CrossRef Medline

Mower AF, Liao DS, Nestler EJ, Neve RL, Ramoa AS (2002) cAMP/Ca ${ }^{2+}$ response element-binding protein function is essential for ocular dominance plasticity. J Neurosci 22:2237-2245. Medline

Muir-Robinson G, Hwang BJ, Feller MB (2002) Retinogeniculate axons undergo eye-specific segregation in the absence of specific layers. J Neurosci 22:5259-5264. Medline

Murakami M, Fleischmann B, De Felipe C, Freichel M, Trost C, Ludwig A, Wissenbach U, Schwegler H, Hofmann F, Hescheler J, Flockerzi V, Cavalié A (2002) Pain perception in mice lacking the beta3 subunit of voltage-activated calcium channels. J Biol Chem 277:40342-40351. CrossRef Medline

Namkung Y, Smith SM, Lee SB, Skrypnyk NV, Kim HL, Chin H, Scheller RH, Tsien RW, Shin HS (1998) Targeted disruption of the Ca2+ channel beta3 subunit reduces $\mathrm{N}$ - and L-type Ca2 + channel activity and alters the voltage-dependent activation of $\mathrm{P} / \mathrm{Q}$-type $\mathrm{Ca} 2+$ channels in neurons. Proc Natl Acad Sci U S A 95:12010-12015. CrossRef Medline

Pham TA, Impey S, Storm DR, Stryker MP (1999) CRE-mediated gene transcription in neocortical neuronal plasticity during the developmental critical period. Neuron 22:63-72. CrossRef Medline

Pham TA, Rubenstein JL, Silva AJ, Storm DR, Stryker MP (2001) The CRE/ CREB pathway is transiently expressed in thalamic circuit development and contributes to refinement of retinogeniculate axons. Neuron 31:409_ 420. CrossRef Medline

Seabrook TA, Krahe TE, Govindaiah G, Guido W (2013) Interneurons in the mouse visual thalamus maintain a high degree of retinal convergence throughout postnatal development. Neural Dev 8:24. CrossRef Medline

Shafer DP, Lehrman EK, Kautzman AG, Koyama R, Mardinly AR, Yamasaki R, Ransohoff RM, Greenburg ME, Barres BA, Stevens B (2012) Neuron 74:691-705. CrossRef Medline

Shiraiwa T, Kashiwayanagi M, Iijima T, Murakami M (2007) Involvement of the calcium channel beta3 subunit in olfactory signal transduction. Biochem Biophys Res Commun 355:1019-1024. CrossRef Medline

Smetters DK, Hahm J, Sur M (1994) An N-methyl-D-aspartate receptor antagonist does not prevent eye-specific segregation in the ferret retinogeniculate pathway. Brain Res 658:168-178. CrossRef Medline

Stevens B, Allen NJ, Vazquez LE, Howell GR, Christopherson KS, Nouri N, Micheva KD, Mehalow AK, Huberman AD, Stafford B, Sher A, Litke AM, Lambris JD, Smith SJ, John SW, Barres BA (2007) The classical complement cascade mediates CNS synapse elimination. Cell 131:1164-1178. CrossRef Medline

Torborg CL, Feller MB (2004) Unbiased analysis of bulk axonal segregation patterns. J Neurosci Methods 135:17-26. CrossRef Medline

Torborg CL, Feller MB (2005) Spontaneous patterned retinal activity and the refinement of retinal projections. Prog Neurobiol 76:213-235. CrossRef Medline

Tropea D, Kreiman G, Lyckman A, Mukherjee S, Yu H, Horng S, Sur M (2006) Gene expression changes and molecular pathways mediating activity-dependent plasticity in visual cortex. Nat Neurosci 9:660-668. CrossRef Medline

Ziburkus J, Guido W (2006) Loss of binocular responses and reduced retinal convergence during the period of retinogeniculate axon segregation. J Neurophysiol 96:2775-2784. CrossRef Medline

Ziburkus J, Dilger EK, Lo FS, Guido W (2009) LTD and LTP at the developing retinogeniculate synapse. J Neurophysiol 102:3082-3090. CrossRef Medline 